\title{
PEMODELAN KETERKAITAN ANTAR FAKTOR KENDALA PENERAPAN TEKNOLOGI TERBATAS (PILOT PROJECT) BIDANG JALAN MELALUI PENYEDIA JASA
}

\author{
Kiki Mohammad Iqbal ${ }^{1}$, Anton Soekiman ${ }^{2}$ \\ ${ }^{1}$ Program Studi Magister Teknik Sipil, Jurusan Manajemen Proyek Konstruksi/ Universitas \\ Katolik Parahyangan Bandung \\ ${ }^{2}$ Fakultas Teknik, Jurusan Teknik Sipil, Universitas Katolik Parahyangan Bandung \\ Korespondensi : kie.iqbal@gmail.com ${ }^{1}$, soekiman@ unpar.ac.id ${ }^{2}$
}

\begin{abstract}
Research and development in the roads sector is one of the coaching tasks of roads authority. To disseminate the results of research required the transfer of technology which one of them through implementation of limited technology. Institute of Road Engineering has carried out the technology transfer process through implementation of limited technology using road contractors. In the implementation project there are interrelated constraints factor that obstruct the performance implementation of limited technology so that the resulting output is not optimal. The purpose of this research is to identify and classify the contextual relationship between the constraints factor in the implementation of limited technology of the road construction using contractors. The method used in this research is Interpretive Structural Modeling. The results showed that the contractor's financial ability problem to finance the work and giving the project to the lowest bid was the most influencing key factor (driver power) in the hierarchical relationship.
\end{abstract}

Keywords : Contextual Relationships, Dependence, Driver Power, ISM, Pilot Project

\section{PENDAHULUAN}

Pusat Penelitian dan Pengembangan Jalan dan Jembatan (Pusjatan) Kementerian Pekerjaan Umum dan Perumahan Rakyat memiliki tugas dan fungsi penelitian bidang jalan dengan lingkup aspek perencanaan umum dan teknis, pemrograman, pelaksanaan konstruksi, pengoperasian dan pemeliharaan, teknologi bahan dan alat, dan tata laksana, pengawasan, dan pengendalian dengan luaran berupa ilmu pengetahuan terapan, teknologi aplikatif, dan kekayaan intelektual [1]. Penerapan teknologi terbatas (pilot project) bidang jalan merupakan implementasi alih teknologi kekayaan intelektual hasil penelitian Pusjatan.

Upaya optimalisasi penerapan teknologi terbatas (pilot project) pada siklus litbang diperlukan keterlibatan penyedia jasa sebagai pelaksana konstruksi. Keterlibatan penyedia jasa untuk menjalin kerjasama penyediaan sumber daya proyek dan transfer pengetahuan. Postur anggaran pelaksanaan (pilot project) sebesar $\quad 75-80 \%$ dilaksanakan secara kontraktual [2].

Pada implementasinya keterlibatan penyedia jasa tidak dapat dihindari adanya risiko dengan ketidakpastian (uncertainty) besar, dikarenakan penggunaan teknologi baru belum diketahui penyedia jasa. Setiap proyek konstruksi memiliki tujuan khusus pada proses pencapaiannya dengan batasan sumber daya proyek yang ada meliputi biaya yang dialokasikan, waktu dan mutu yang harus dipenuhi batasan tersebut dikenal dengan triple constraint. Pada kondisi optimal batasanbatasan tersebut memiliki hubungan saling tergantung (dependent) serta berpengaruh kuat (driver power) dengan kepekaan tinggi, jika salah satu darinya berubah akan langsung berdampak pada batasan lain sehingga hal tersebut sulit dicegah pengaruhnya. Akibatnya menimbulkan kendala pelaksanaan konstruksi jika tidak dikelola maka dapat menyebabkan keterlambatan hingga kegagalan proyek.

Pada penelitian sebelumnya, analisis faktor paling mempengaruhi pilot project 
bidang jalan dilakukan melalui penentuan rangking berdasarkan pembobotan faktor [3], akan tetapi hasil faktor bobot tertinggi tidak bisa secara otomatis menjadi prioritas utama penentu keberhasilan pelaksanaan proyek karena pada dasarnya antar elemen sumber daya proyek memiliki hubungan keterkaitan. Contohnya, kurangnya pengetahuan dasar terhadap teknologi yang dikembangkan dapat menyebabkan ketidaksesuaian metode kerja menyebabkan spesifikasi tidak dapat dipenuhi dan pada akhirnya menyebabkan rendahnya kualitas hasil pelaksanaan konstruksi.

Berdasarkan isu tersebut pada penelitian ini dilakukan pemodelan keterkaitan antar faktor kendala penerapan teknologi terbatas (pilot project) bidang jalan melalui penyedia jasa menggunakan metode ISM (interpretive structural modelling) untuk menyederhanakan masalah dalam sistem yang kompleks dengan cara menyusun urutan dan arah sistem secara terstruktur serta menghasilkan klasfikasikan setiap faktor menggunakan analisis MICMAC berdasarkan hasil hubungan kontekstual antar faktor guna mendukung pengambilan keputusan menetapkan prioritas penyelesaian masalah.

\section{TINJAUAN PUSTAKA}

\subsection{Penerapan Teknologi Terbatas (Pilot Project) Pusjatan}

Penerapan teknologi terbatas (pilot project) adalah pelaksanaan kegiatan proyek percontohan yang dirancang sebagai pengujian skala lapangan atau trial dalam rangka untuk menunjukkan keefektifan dan dampak pelaksanaan program [2]. Dalam lingkup Pusjatan secara umum pelaksanaan konstruksi penerapan teknologi terbatas (pilot project) dilaksanakan melalui kontraktual dalam rangkaian siklus penelitian dan pengembangan (Litbang) teknologi yang dihasilkan oleh Balai Bahan dan Perkerasan Jalan, Balai Geoteknik Jalan, Balai Struktur Jembatan serta Balai Sistem dan Teknik Lalu Lintas.

Tidak semuanya teknologi yang sedang diteliti/dikembangkan dapat ditindak lanjuti menjadi penerapan teknologi terbatas (pilot project) diharuskan memenuhi seluruh kriteria dalam Tingkat Kesiapan Teknologi (TKT) yang diukur skala 1-9 untuk kesiapannya. TKT merupakan suatu sistem pengukuran sistematik yang mendukung penilaian kematangan atau kesiapan dari suatu teknologi tertentu dan perbandingan kematangan atau kesiapan antara jenis teknologi yang berbeda. Teknologi litbang yang sudah memenuhi kriteria layak (nilai TKT 7) maka siap masuk ke level replikasi dan industrialisasi.

\subsection{Definisi Jalan}

Jalan adalah prasarana transportasi darat yang meliputi segala bagian jalan, termasuk bangunan pelengkap dan perlengkapannya yang diperuntukkan bagi lalu lintas, yang berada pada permukaan tanah, di atas permukaan tanah, di bawah permukaan tanah dan/atau air, serta di atas permukaan air, kecuali jalan kereta api, jalan lori, dan jalan kabel [4].

Salah satu tugas pembinaan jalan nasional meliputi penelitian dan pengembangan jalan. Pengkajian serta penelitian dan pengembangan teknologi bidang jalan dan yang terkait bidang jalan dilakukan secara menerus untuk meningkatkan keandalan jalan, mengembangkan potensi sumber daya alam setempat dan memberi nilai tambah dalam penyelenggaraan jalan. Pembinaan yang dimaksud mendorong inovasi teknologi, penelitian dan pengembangan, dan verifikasi teknologi dalam rangka implementasi konstruksi berkelanjutan pada penyelenggaraan infrastruktur.[4][5]

\subsection{Penyedia Jasa}

Penyedia Barang/jasa yang selanjutnya disebut Penyedia adalah pelaku usaha yang menyediakan barang/jasa berdasarkan kontrak [6].

\section{METODE PENELITIAN}

Metode penelitian yang digunakan bersifat kualitatif, teknik pengumpulan data penelitian ini dengan menggali pengalaman dan pengetahuan anggota kelompok praktisi melalui wawancara semi-terstruktur dan kuesioner pada identifikasi faktor kendala sedangkan dalam identifikasi hubungan kontekstual antar faktor kendala menggunakan teknik puteran Delphi untuk mencapai konsensus, analisis data menggunakan metode ISM (interpretive structural modelling) dan analisis MICMAC. Metodologi penelitian dalam penelitian ini dapat dilihat di Gambar 1.

Data yang digunakan dalam penelitian ini adalah data primer dan data sekunder. Data primer diperoleh melalui wawancara semi 
terstruktur dan kuesioner kepada para anggota praktisi memiliki latar belakang pendidikan sekurang-kurangnya S1 Teknik Sipil dan memiliki pengalaman sekurang-kurangnya 5 tahun pada proyek ini. Data sekunder diperoleh dari hasil kajian literatur (jurnal, Peraturan Menteri Pekerjaan Umum No. 07/PRT/M/2012, dokumen Renstra Balitbang tahun 2016-2019, laporan konsultan supervisi). Hasil faktor kendala yang telah terinventarisasi disusun dalam kuesioner ke-1 dan dilakukan wawancara untuk validasi kepada 17 anggota kelompok praktisi.

Faktor kendala hasil validasi, selanjutnya disusun ke dalam kuesioner ke-2 untuk mengidentifikasi hubungan kontekstual antar faktor kendala melalui matrik pasangan (pairwise) menggunakan metode ISM kepada 8 anggota kelompok praktisi. Setelah didapatkan hasil identifikasi dilakukan analisis data menggunakan software ISM Win.1.1.

\section{ANALISIS DAN PEMBAHASAN \\ 4.1 Pengumpulan Data}

Pengumpulan data dilakukan dari bulan Maret sampai Juni 2020.

4.1.1 Identifikasi Faktor Kendala Penerapan Teknologi Terbatas (Pilot Project) Bidang Jalan Melalui Penyedia Jasa

Pada tahapan penelitian ini faktor-faktor hasil kajian literatur yang telah didapatkan dikelompokan berdasarkan 5 batasan (constraints) sumber daya proyek yang terdiri biaya, mutu, waktu, keamanan, kesehatan dan keselamatan kerja (K3) serta lingkungan kemudian dielaborasikan dengan wawancara semi terstruktur dan kuesioner ke-1 kepada anggota praktisi menggunakan justifikasi suara terbanyak hasil dari selection of experts (by experience) dengan ambang batas 50\%+1 dari total suara 17 anggota praktisi terhadap 52 faktor dalam wawancara dan kuesioner ke-1 menghasilkan 23 faktor kendala yang tervalidasi.

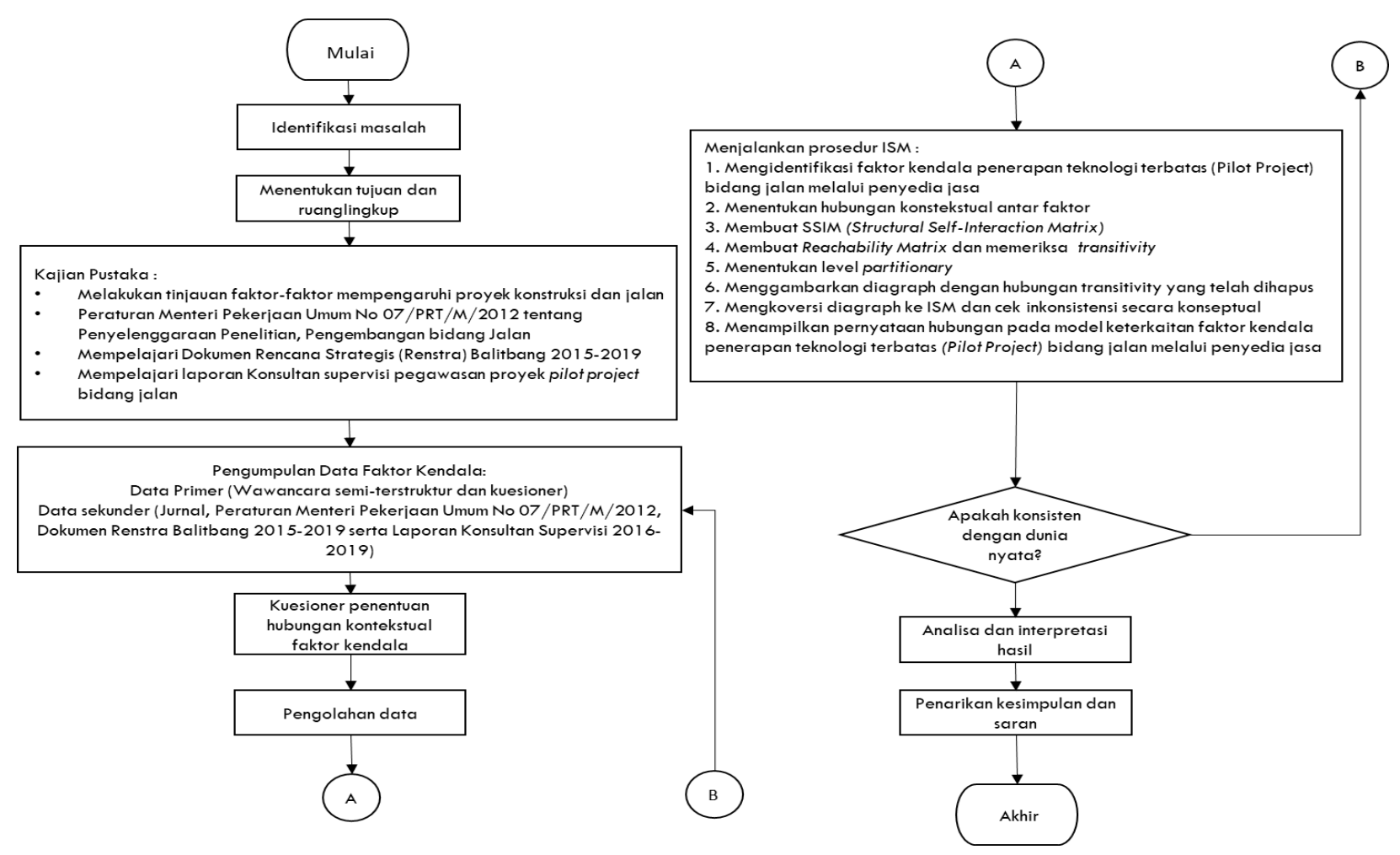

Gambar 1. Metodologi Penelitian 
Pada Tabel 1 disajikan hasil identifikasi faktor kendala penerapan teknologi terbatas (pilot project) bidang jalan melalui penyedia jasa.

\subsubsection{Identifikasi Hubungan Kontekstual Antar Faktor Kendala Penerapan Teknologi Terbatas (Pilot Project) Bidang Jalan Melalui Penyedia Jasa}

Berdasarkan hasil identifikasi faktor, 23 faktor tersebut disusun ke dalam kuesioner ke-2 secara matrik berpasangan menggunakan metode ISM, penyebaran dan pengumpulan data kuesioner ke-2 kepada 8 anggota praktisi, terdapat 506 matrik (23x23 dikurangi diagonal matrik yang menggambarkan perbandingan terhadap faktor itu sendiri), penggunaan teknik puteran delphi membantu setiap puterannya mendapatkan kesamaan interpretasi.

Dengan mempertimbangkan jumlah matrik faktor yang akan divalidasi dengan 4 opsi pilihan identifikasi hubungan $(\mathrm{V}, \mathrm{A}, \mathrm{O}, \mathrm{X})$ setiap matriknya, diperlukan identifikasi persentase level konsensus sebagai ambang batas. Secara umum tidak ada aturan untuk menentukan persentase ambang batas pada penelitian dengan teknik Delphi [7]. Konsensus akan muncul pada persentase level yang tinggi $100 \%$ [8]. Sementara penelitian lain menetapkan ambang konsensus $51 \%$ dari responden [7]. Atas dasar tersebut penetapan persentase level konsensus pada penelitian ini dengan ambang batas $50 \%+1$ terhadap interpretasi hubungan kontektual antar faktor. Proses selanjutnya mengembangkan structural self-interaction matrix (SSIM) menggunakan aturan sebagai berikut

a. V untuk hubungan dari faktor $i$ ke faktor $j$ (faktor i akan mempengaruhi faktor j).

b. A untuk hubungan faktor $\mathrm{j}$ ke faktor i (faktor i akan dipengaruhi oleh aktor j).

c. X untuk hubungan dua arah (faktor $\mathrm{i}$ dan $\mathrm{j}$ akan mempengaruhi satu sama lain).

d. O untuk tidak ada hubungan antar faktor (faktor i dan $\mathrm{j}$ tidak berhubungan).

Secara persentase hasil proses puteran delphi sebagai berikut, puteran ke-1: $30,43 \%$, puteran ke-2: 87,75\%, puteran ke-3: 92,09\% dan puteran ke-4: $100 \%$.

Tabel 1. Faktor Kendala Penerapan Teknologi Terbatas (Pilot Project) Bidang Jalan Melalui Penyedia Jasa

\begin{tabular}{|c|c|}
\hline \multirow[t]{2}{*}{ Biaya } & $\begin{array}{l}\text { Masalah kemampuan keuangan kontraktor membiayai } \\
\text { pekerjaan }\end{array}$ \\
\hline & Memberikan proyek kepada penawaran terendah \\
\hline \multirow{18}{*}{ Mutu } & Rendahnya manajemen ketersediaan peralatan konstruksi \\
\hline & Rendahnya pengelolaan personil organisasi. \\
\hline & Rendahnya kemampuan teknis manajer proyek \\
\hline & Rendahnya kompetensi tenaga kerja \\
\hline & Personil kurang pengalaman pekerjaan sejenis \\
\hline & Perubahan kondisi pekerjaan lapangan \\
\hline & Perubahan desain \\
\hline & Rendahnya kinerja subkontraktor \\
\hline & Rendahnya keakuratan data utilitas jalan \\
\hline & $\begin{array}{l}\text { Ketidaksesuian hasil studi kelayakan (feasibility Study) } \\
\text { dengan kondisi lapangan }\end{array}$ \\
\hline & $\begin{array}{l}\text { Kesulitan pemahaman standar, pedoman, manual teknologi } \\
\text { yang tersedia dalam metode pelaksanaan konstruksi }\end{array}$ \\
\hline & $\begin{array}{l}\text { Rendahnya pengetahuan dasar penyedia jasa terhadap } \\
\text { teknologi bidang jalan yang dikembangkan }\end{array}$ \\
\hline & Penentuan Project Delivery System (Sistem pengadaan) \\
\hline & $\begin{array}{l}\text { Permasalahan impor pengadaan alat maupun material } \\
\text { khusus }\end{array}$ \\
\hline & $\begin{array}{l}\text { Penentuan penanggung jawaban risiko kegagalan proyek } \\
\text { penelitian }\end{array}$ \\
\hline & Kurangnya dukungan teknis dari konsultan \\
\hline & $\begin{array}{l}\text { Kurangnya proses pertukaran pengetahuan teknologi jalan } \\
\text { yang dikembangkan }\end{array}$ \\
\hline & Kontraktor kurang pengalaman pekerjaan sejenis \\
\hline Waktu & Rendahnya kualitas penjadwalan pelaksanaan proyek \\
\hline okur & Gangguan pihak ekternal diluar pihak internal terkait proyek \\
\hline & Kondisi cuaca sulit diprediksi \\
\hline
\end{tabular}

Rekapitulasi hasil identifikasi hubungan kontektual antar faktor kendala penerapan teknologi terbatas (pilot project) bidang jalan melalui penyedia jasa yang dalam tahapan metode ISM adalah structural self-interaction matrix (SSIM). 
Tabel 2. Structural Self-Interaction Matrix (SSIM)

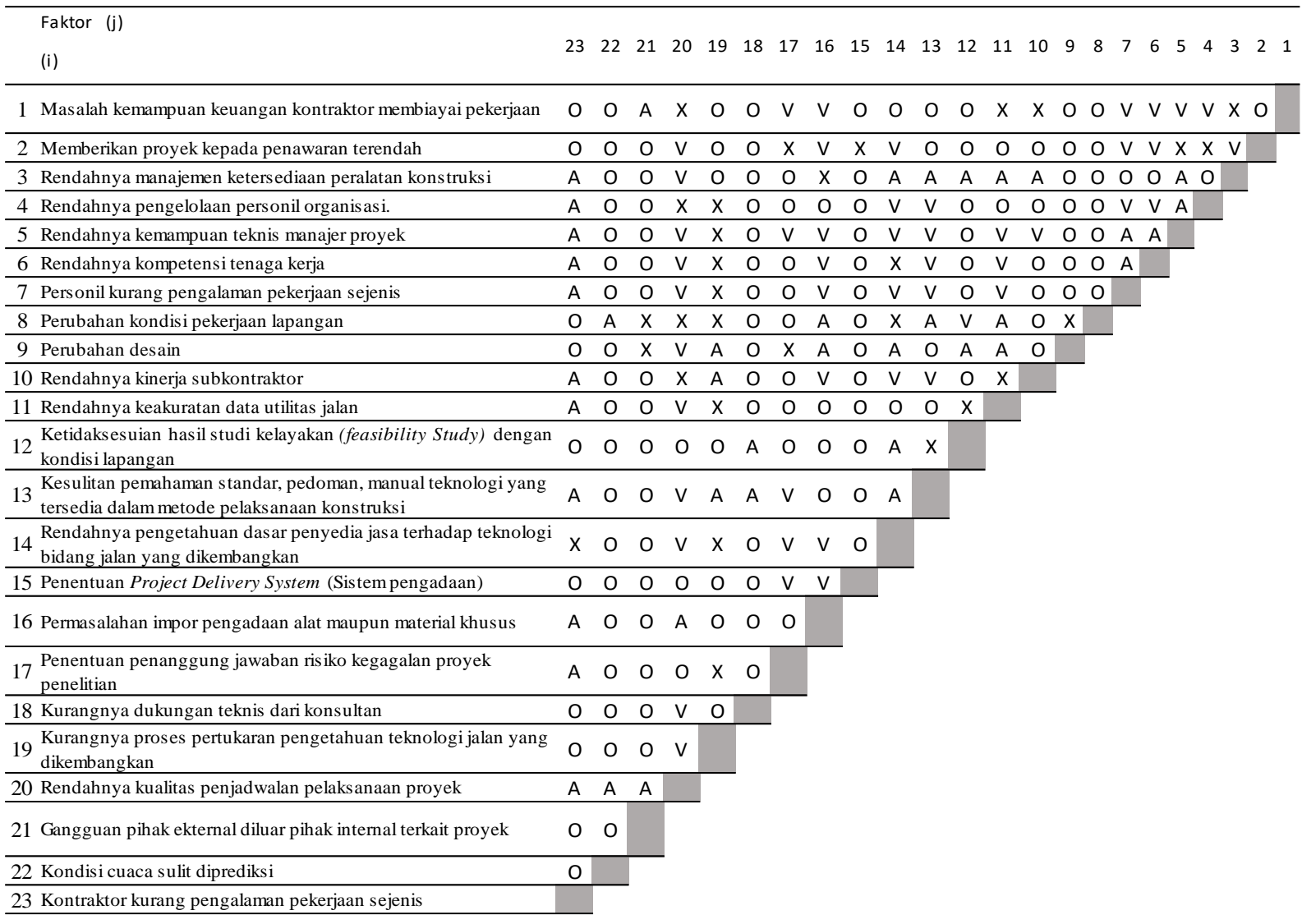

\subsection{Pengolahan Data}

\subsubsection{Reachability Matrix}

Tahap ini merubah SSIM menjadi matrik biner dengan mengkonversi simbol $\mathrm{V}, \mathrm{A}, \mathrm{X}, \mathrm{O}$ ke dalam angka 0 dan 1 . Aturan konversi sebagai berikut :

$(\mathrm{i}, \mathrm{j})=\mathrm{V}=1,(\mathrm{j}, \mathrm{i})=0$

$(\mathrm{i}, \mathrm{j})=\mathrm{A}=0,(\mathrm{j}, \mathrm{i})=1$

$(\mathrm{i}, \mathrm{j})=\mathrm{X}=1,(\mathrm{j}, \mathrm{i})=1$

$(\mathrm{i}, \mathrm{j})=\mathrm{O}=0,(\mathrm{j}, \mathrm{i})=0$

Final reachability matrix memeriksa transitivitas hubungan tidak langsung antar faktor dengan asumsi dasar yang menyatakan bahwa jika elemen $\mathrm{A}$ terkait dengan $\mathrm{B}$ dan $\mathrm{B}$ terkait dengan $\mathrm{C}$, maka $\mathrm{A}$ terkait dengan $\mathrm{C}$. Pada Tabel 3 disajikan final reachability matrix.

\subsubsection{Partisi Reachability Matrix Ke Level Yang Berbeda}

Partisi level seluruh faktor yang ada dengan menentukan reachability set dan anteseden set dari setiap faktor, tentukan intersection pada setiap level berbeda dalam membangun model ISM. Penelitian ini menghasilkan 9 matrik iterasi.
Pada Tabel 4 iterasi ke-1, faktor 12, 13, 16, 20 masuk level 1 berada pada posisi paling atas (paling dipengaruhi), proses iterasi ke-2 faktor kendala yang terpilih pada iterasi ke-1 tidak masuk dalam proses iterasi ke-2. Proses dilakukan berulang hingga seluruh faktor memiliki level.

Tabel 3. Final Reachability Matrix

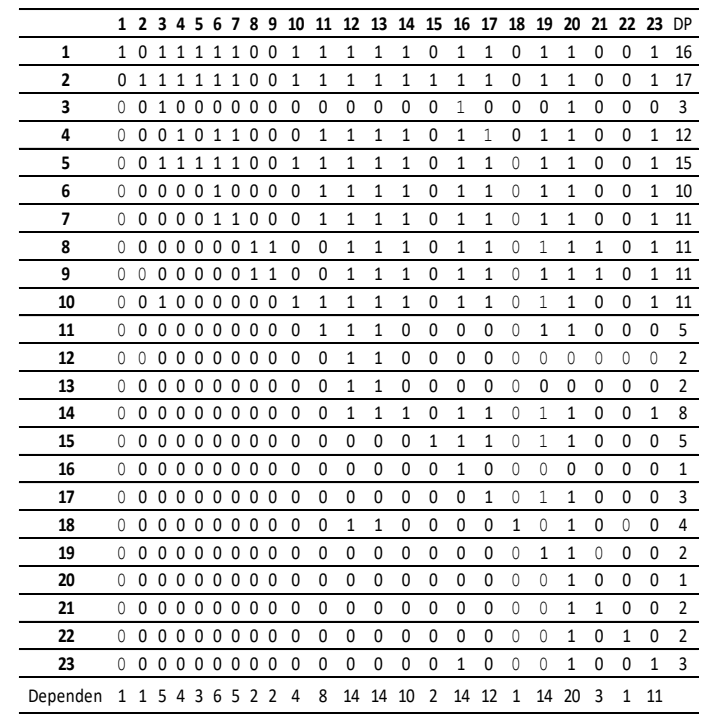


Tabel 4. Iterasi Ke-1

\begin{tabular}{|c|c|c|c|c|}
\hline Element & $\begin{array}{c}\text { Reachability Set } \\
\end{array}$ & Antecedent set & Intersection & Level \\
\hline 1 & $1,3,4,5,6,7,10,11,12,13,14,16,17,19,20,23$ & 1 & 1 & \\
\hline 2 & $2,3,4,5,6,7,10,11,12,13,14,15,16,17,19,20,23$ & 2 & 2 & \\
\hline 3 & $3,16,20$ & $1,2,3,5,10$ & 3 & \\
\hline 5 & $3,4,5,6,7,10,11,12,13,14,16,17,19,20,23$ & $1,2,5$ & 5 & \\
\hline 6 & $6,11,12,13,14,16,17,19,20,23$ & $1,2,4,5,6,7$ & 6 & \\
\hline 9 & $8,9,12,13,14,16,17,19,20,21,23$ & 8,9 & 8,9 & \\
\hline 10 & $3,10,11,12,13,14,16,17,19,20,23$ & $1,2,5,10$ & 10 & \\
\hline 11 & $11,12,13,19,20$ & $1,2,4,5,6,7,10,11$ & 11 & \\
\hline 12 & 12,13 & $1,2,4,5,6,7,8,9,10,11,12,13,14,18$ & 12,13 & 1 \\
\hline 13 & 12,13 & $1,2,4,5,6,7,8,9,10,11,12,13,14,18$ & 12,13 & 1 \\
\hline 18 & $12,13,18,20$ & 18 & 18 & \\
\hline 19 & 19,20 & $1,2,4,5,6,7,8,9,10,11,14,15,17,19$ & 19 & \\
\hline 20 & 20 & $1,2,3,4,5,6,7,8,9,10,11,14,15,17,18,19,20,21,22,23$ & 20 & 1 \\
\hline 21 & 20,21 & $8,9,21$ & 21 & \\
\hline 22 & 20,22 & 22 & 22 & \\
\hline 23 & $16,20,23$ & $1,2,4,5,6,7,8,9,10,14,23$ & 23 & \\
\hline
\end{tabular}

Pada Tabel 5 faktor 1 dan 2 masuk ke dalam level 9, faktor pada level ini menjadi faktor kunci paling mempengaruhi faktor level diatasnya.

Tabel 5. Iterasi Terakhir (ke-9)

\begin{tabular}{ccccc}
\hline Element & Reachability Set & Antecedent set & Intersection & Level \\
\hline 1 & 1 & 1 & 1 & 9 \\
\hline 2 & 2 & 2 & 2 & 9 \\
\hline
\end{tabular}

\subsection{Menyusun Diagram Conical}

Mengurutkan secara hierarki berdasarkan level faktor serta menggambarkan hubungan pengaruh antar level faktor pada tahap diagram diagraph. Disajikan pada Tabel 6.

\subsection{Mengembangkan Diagram Diagraph}

Berbasis conical matrix hasil dari reachability matrix kemudian diagram diagraph disusun melalui simbol garis dan node, faktor level ke-1 diposisikan di paling atas dan faktor level ke-2 ditempatkan pada posisi kedua dan seterusnya, sampai pada level posisi terendah

\subsection{Klasifikasi Faktor Kendala Menggunakan Analisis MICMAC}

Klasifikasi faktor berdasarkan final reachability matrix, dikelompokan dalam 4 kategori diantaranya, independent, linkage, dependence, autonomous. Hasil klasifikasi tersaji pada Gambar 2.
Tabel 6. Diagram Conical

\begin{tabular}{|c|c|c|c|c|c|c|c|c|c|c|c|c|c|c|c|c|c|}
\hline \multicolumn{18}{|c|}{ 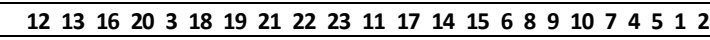 } \\
\hline 12 & 1 & 1 & 0 & 0 & & & & & & 0 & & & 0 & 0 & & 0 & 000000 \\
\hline 13 & 1 & 1 & 0 & 0 & & & 5 & & j & 0 & 0 & 0 & 0 & 0 & 000 & 0 & 000000 \\
\hline 16 & 0 & 0 & 1 & 0 & & & & & o & 0 & 0 & & 0 & & 000 & & 000000 \\
\hline 20 & 0 & 0 & 0 & 1 & & & & & 0 & 0 & 0 & 0 & 0 & 0 & 000 & 0 & 00000 \\
\hline 3 & 0 & 0 & 1 & 1. & & & 5 & & 0 & 0 & 0 & 0 & 0 & 0 & 000 & 0 & 00000 \\
\hline 18 & 1 & 1 & 0 & 1 & & 1 & 5 & & 0 & 0 & 0 & 0 & 0 & 0 & 000 & 0 & 00000 \\
\hline 19 & 0 & 0 & 0 & 1 & & 0 & 1 & & 0 & 0 & 0 & 0 & 0 & 0 & 000 & 0 & 00000 \\
\hline 21 & 0 & 0 & 0 & 1 & & 0 & 5 & & 0 & 0 & 0 & 0 & 0 & 0 & $\begin{array}{llll}0 & 0 & 0\end{array}$ & 0 & 00000 \\
\hline 22 & 0 & 0 & 0 & 1 & & 0 & 5 & & 1 & 0 & 0 & 0 & 0 & 0 & $\begin{array}{llll}0 & 0 & 0 \\
\end{array}$ & 0 & 00000 \\
\hline 23 & 0 & 0 & 1 & 1 & 00 & 0 & 5 & 5 & 0 & 1 & 0 & 0 & 0 & 0 & $\begin{array}{llll}0 & 0 & 0\end{array}$ & 0 & 00000 \\
\hline 11 & 1 & 1 & 0 & 1 & 00 & 0 & 1 & 5 & 0 & 0 & 1 & 0 & 0 & 0 & $\begin{array}{llll}0 & 0 & 0\end{array}$ & & 00000 \\
\hline 17 & 0 & 0 & 0 & 1 & 00 & & 1 & 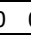 & 0 & 0 & 0 & 1 & 0 & 0 & $\begin{array}{llll}0 & 0 & 0\end{array}$ & & $\begin{array}{lllll}0 & 0 & 0 & 0 & 0\end{array}$ \\
\hline 14 & 1 & 1 & 1 & 1 & 00 & 0 & 1 & 5 & 0 & 1 & 0 & 1 & 1 & 0 & $\begin{array}{llll}0 & 0 & 0\end{array}$ & & 00000 \\
\hline 15 & 0 & 0 & 1 & 1 & 00 & 0 & 1 & & 0 & 0 & 0 & 1 & 0 & 1 & $\begin{array}{llll}0 & 0 & 0\end{array}$ & & 00000 \\
\hline 6 & 1 & 1 & 1 & 1 & 0 & 0 & 1 & & 0 & 1 & 1 & 1 & 1 & 0 & 100 & & 00000 \\
\hline 8 & 1 & 1 & 1 & 1 & 00 & 0 & 1 & 1 & 0 & 1 & 0 & 1 & 1 & 0 & $\begin{array}{llll}0 & 1 & 1\end{array}$ & & 00000 \\
\hline 9 & 1 & 1 & 1 & 1 & 00 & 0 & 1 & 1 & 0 & 1 & 0 & 1 & 1 & 0 & $\begin{array}{llll}0 & 1 & 1 \\
\end{array}$ & 0 & 00000 \\
\hline 10 & 1 & 1 & 1 & 1 & 10 & 0 & 1 & 5 & 0 & 1 & 1 & 1 & 1 & 0 & $\begin{array}{llll}0 & 0 & 0\end{array}$ & & 00000 \\
\hline & 1 & 1 & 1 & 1 & 00 & 0 & 1 & 5 & 0 & 1 & 1 & 1 & 1 & U & $\begin{array}{llll}1 & 0 & 0\end{array}$ & 0 & 10000 \\
\hline 4 & 1 & 1 & 1 & 1 & 00 & 0 & 1 & 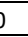 & & 1 & 1 & 1 & 1 & 0 & 100 & & 11000 \\
\hline & 1 & 1 & 1 & 1 & 10 & 0 & 1 & 5 & 0 & 1 & 1 & 1 & 1 & 0 & 100 & 1 & 11100 \\
\hline 1 & 1 & 1 & 1 & 1 & 10 & 0 & 1 & 5 & 0 & 1 & 1 & 1 & 1 & 0 & 100 & & 11110 \\
\hline & 1 & & 1 & 1 & 10 & 0 & 10 & 5 & 0 & 1 & 1 & 1 & 1 & & 100 & & 11101 \\
\hline
\end{tabular}

Terdapat 4 faktor dalam kategori independent factor, diantaranya masalah kemampuan keuangan kontraktor membiayai pekerjaan (1), memberikan proyek kepada penawaran terendah (2), rendahnya pengelolaan personil organisasi (4) dan rendahnya kemampuan teknis manajer proyek (5). Faktor masalah kemampuan keuangan kontraktor membiayai pekerjaan (1), dan faktor memberikan proyek kepada penawaran 


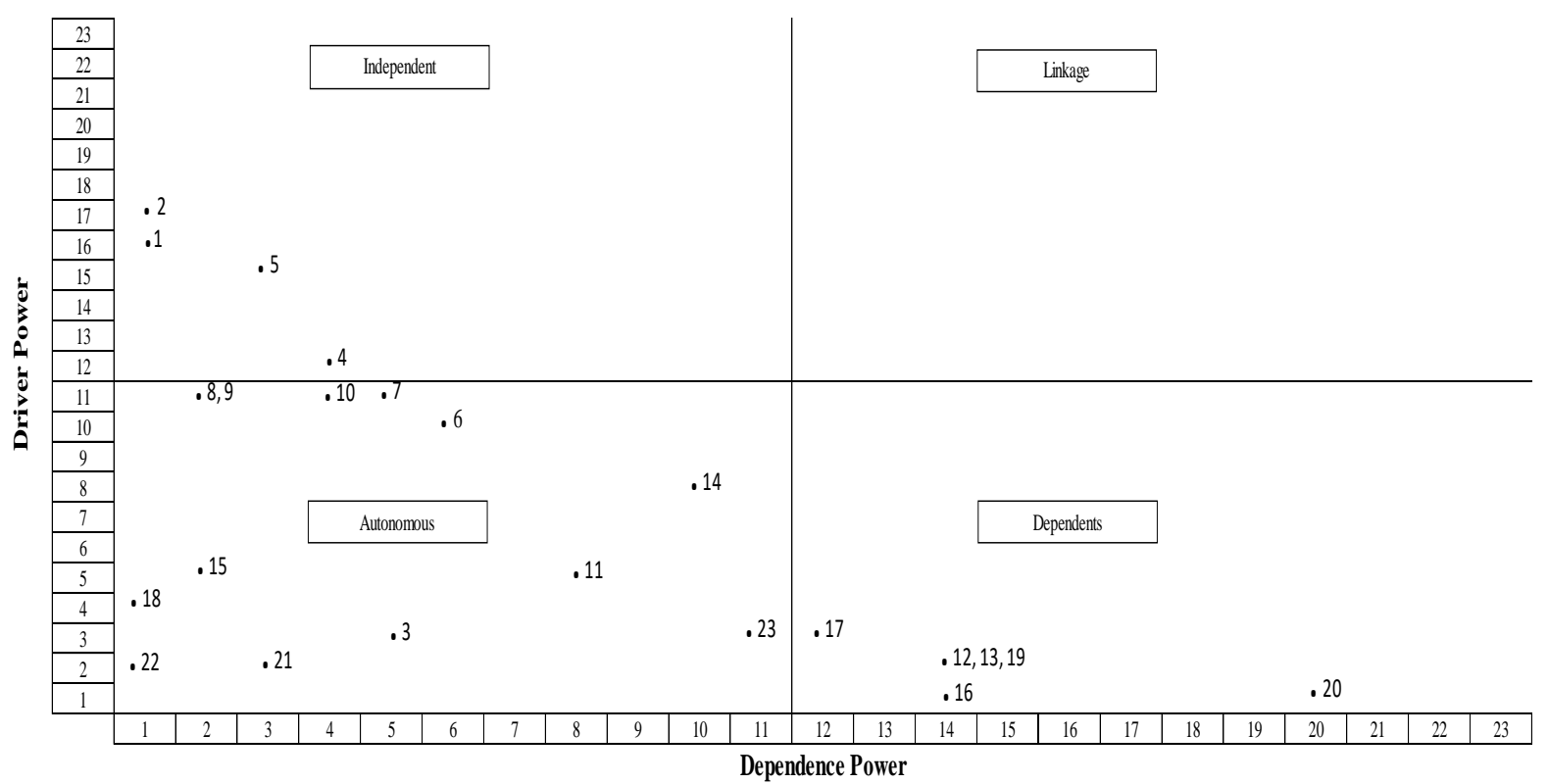

Gambar 2. Klasifikasi Faktor Kendala Penerapan Teknologi Terbatas (Pilot Project) Bidang Jalan Melalui Penyedia Jasa

terendah (2) menjadi faktor dengan (driver power) tertinggi.

Pada kategori linkage factor tidak ada faktor kendala yang termasuk kategori tersebut. Hal itu menggambarkan bahwa tidak ada faktor kendala yang memiliki tingkat pengaruh (driver power) dengan tingkat ketergantungan (dependence) yang kuat dalam hubungan konstektual antar faktor kendala penerapan teknologi terbatas Pilot Project bidang jalan.

Terdapat 6 faktor yang masuk dalam kategori dependence factor diantaranya, rendahnya kualitas penjadwalan pelaksanaan proyek (20), kurangnya proses pertukaran pengetahuan teknologi jalan yang dikembangkan (19), penentuan penanggung jawaban risiko kegagalan proyek penelitian (17), permasalahan impor pengadaan alat maupun material khusus (16), kesulitan pemahaman standar, pedoman, manual teknologi yang tersedia dalam metode pelaksanaan konstruksi (13), ketidaksesuian hasil studi kelayakan (feasibility Study) dengan kondisi lapangan (12). Faktor rendahnya kualitas penjadwalan pelaksanaan proyek (20) menjadi faktor paling dipengaruhi/tergantung faktor lainnya.

Sedangkan mayoritas (13 dari 23 faktor kendala) termasuk kategori autonomous factor diantaranya, kondisi cuaca sulit diprediksi (22), kurangnya dukungan teknis dari konsultan (18), penentuan project delivery system (sistem pengadaan) (15), Perubahan kondisi pekerjaan lapangan (8), perubahan desain (9), gangguan pihak ekternal diluar pihak internal terkait proyek (21), rendahnya kinerja subkontraktor, personil kurang pengalaman pekerjaan sejenis (7), rendahnya manajemen ketersediaan peralatan konstruksi (3), rendahnya kompetensi tenaga kerja (6), rendahnya keakuratan data utilitas jalan (11), rendahnya pengetahuan dasar penyedia jasa terhadap teknologi bidang jalan yang dikembangkan (14), kontraktor kurang pengalaman pekerjaan sejenis (23). Hasil kategori tersebut menggambarkan sebagian besar faktor kendala yang ada memiliki keterkaitan rendah untuk mempengaruhi maupun dipengaruhi

\subsection{Pemodelan Keterkaitan Antar Faktor Kendala Penerapan Teknologi Terbatas (Pilot Project) Bidang Jalan Melalui Penyedia Jasa}

Berdasarkan hasil diagram diagraph mengganti node dengan statement dan menghilangkan hubungan tidak langsung antar faktor, di susun model keterkaitan antar faktor kendala dengan 9 level hierarki faktor yang dikelompokan dalam 3 kluster (top level, middle level, bottom level). Diantaranya :

\section{a. Top Level}

Faktor kendala yang berada pada level kategori ini memiliki driver power (DP) yang lemah dengan tingkat ketergantungan antar 
faktor yang kuat, artinya faktor kendala yang berada pada top level memiliki ketergantungan untuk dipengaruhi oleh faktor-faktor kendala yang berada pada level di bawahnya. Pada kluster ini terdiri dari level 1, 2, 3 dengan 12 faktor kendala. Pada level 1 terdiri dari 4 faktor kendala yaitu, rendahnya kualitas penjadwalan pelaksanaan proyek (20), permasalahan impor pengadaan alat maupun material khusus (16), kesulitan pemahaman standar, pedoman, manual teknologi yang tersedia dalam metode pelaksanaan konstruksi (13), ketidaksesuian hasil studi kelayakan (feasibility Study) dengan kondisi lapangan (12). Pada level 2 terdiri dari 6 faktor kendala yaitu, kontraktor kurang pengalaman pekerjaan sejenis (23), kondisi cuaca sulit diprediksi (22), gangguan pihak ekternal diluar pihak internal terkait proyek (21), kurangnya proses pertukaran pengetahuan teknologi jalan yang dikembangkan (19), kurangnya dukungan teknis dari konsultan (18), rendahnya manajemen ketersediaan peralatan konstruksi (3). Pada level 3 terdiri dari 2 faktor kendala yaitu, rendahnya keakuratan data utilitas jalan (11), penentuan penanggung jawaban risiko kegagalan proyek penelitian (17).

Pada kluster top level didapatkan 3 faktor kendala pada level 1 dengan tingkat dependence tinggi diantaranya, rendahnya kualitas penjadwalan pelaksanaan proyek (20), permasalahan impor pengadaan alat maupun material khusus (16), dan ketidaksesuian hasil studi kelayakan (feasibility Study) dengan kondisi lapangan (12). Sedangkan faktor kendala rendahnya kualitas penjadwalan pelaksanaan proyek (20) merupakan faktor kendala dengan tingkat dependence tertinggi diantara 3 faktor tersebut.

\section{b. Middle Level}

Pada kluster ini terdiri dari level 4, 5, 6 dengan 7 faktor kendala. Pada level 4 terdiri dari 2 faktor kendala yaitu, rendahnya pengetahuan dasar penyedia jasa terhadap teknologi bidang jalan yang dikembangkan (14), dan penentuan Project Delivery System (Sistem pengadaan) (15). Pada level 5 terdiri dari 4 faktor kendala yaitu, rendahnya kompetensi tenaga kerja (6), perubahan kondisi pekerjaan lapangan (8), perubahan desain (9), rendahnya kinerja subkontraktor (10). Pada level 6 terdiri dari 1 faktor kendala yaitu, personil kurang pengalaman pekerjaan sejenis (7).

Pada kluster ini didapatkan 1 faktor kendala level 4 dengan tingkat dependence tertinggi yaitu, rendahnya pengetahuan dasar penyedia jasa terhadap teknologi bidang jalan yang dikembangkan (14). Faktor ini menjadi penghubung antara pengaruh dari faktor kendala bottom level kepada top level.

\section{c. Bottom Level}

Level ini berada pada kluser terbawah pada struktur hirarki ISM, faktor yang berada pada bottom level memiliki tingkat mempengaruhi (driver power) yang kuat dengan ketergantungan (dependence) yang lemah. Pada kluster ini terdiri dari level 7, 8, 9 dengan 4 faktor kendala yaitu, rendahnya pengelolaan personil organisasi (4), rendahnya kemampuan teknis manajer proyek (5), memberikan proyek kepada penawaran terendah (2) dan masalah kemampuan keuangan kontraktor membiayai pekerjaan (1).

Pada kluster ini didapatkan 2 faktor kendala pada level 9 dengan tingkat driver power tertinggi diantaranya, memberikan proyek kepada penawaran terendah. (2) dan masalah kemampuan keuangan kontraktor membiayai pekerjaan. (1). Kedua faktor kendala tersebut menjadi faktor kunci paling mempengaruhi dan mendorong terjadinya faktor kendala lain dalam struktur hubungan kontekstual hierarki. Pada Gambar 3. disajikan hasil pemodelan keterkaitan faktor kendala penerapan teknologi terbatas (pilot project) bidang jalan melalui penyedia jasa.

Berdasarkan hasil pemodelan, terdapat keterkaitan hubungan pengaruh pada 3 kluster (top level, middle level, bottom level) terdiri dari level 1 hingga level 9 dengan 3 klasifikasi faktor (dependence, autonomous, independent) yang membentuk rantai hubungan pengaruh secara hierarki pada faktor kendala penerapan teknologi terbatas (pilot project) bidang jalan. Dalam upaya menghilangkan pemicu terbentuk rantai hubungan pengaruh maka kedua faktor kunci menjadi prioritas untuk diselesaikan.

\section{KESIMPULAN} berikut:

Kesimpulan pada penelitian ini sebagai

a. Terdapat 23 faktor kendala penerapan teknologi terbatas (pilot project) bidang jalan melalui penyedia jasa 


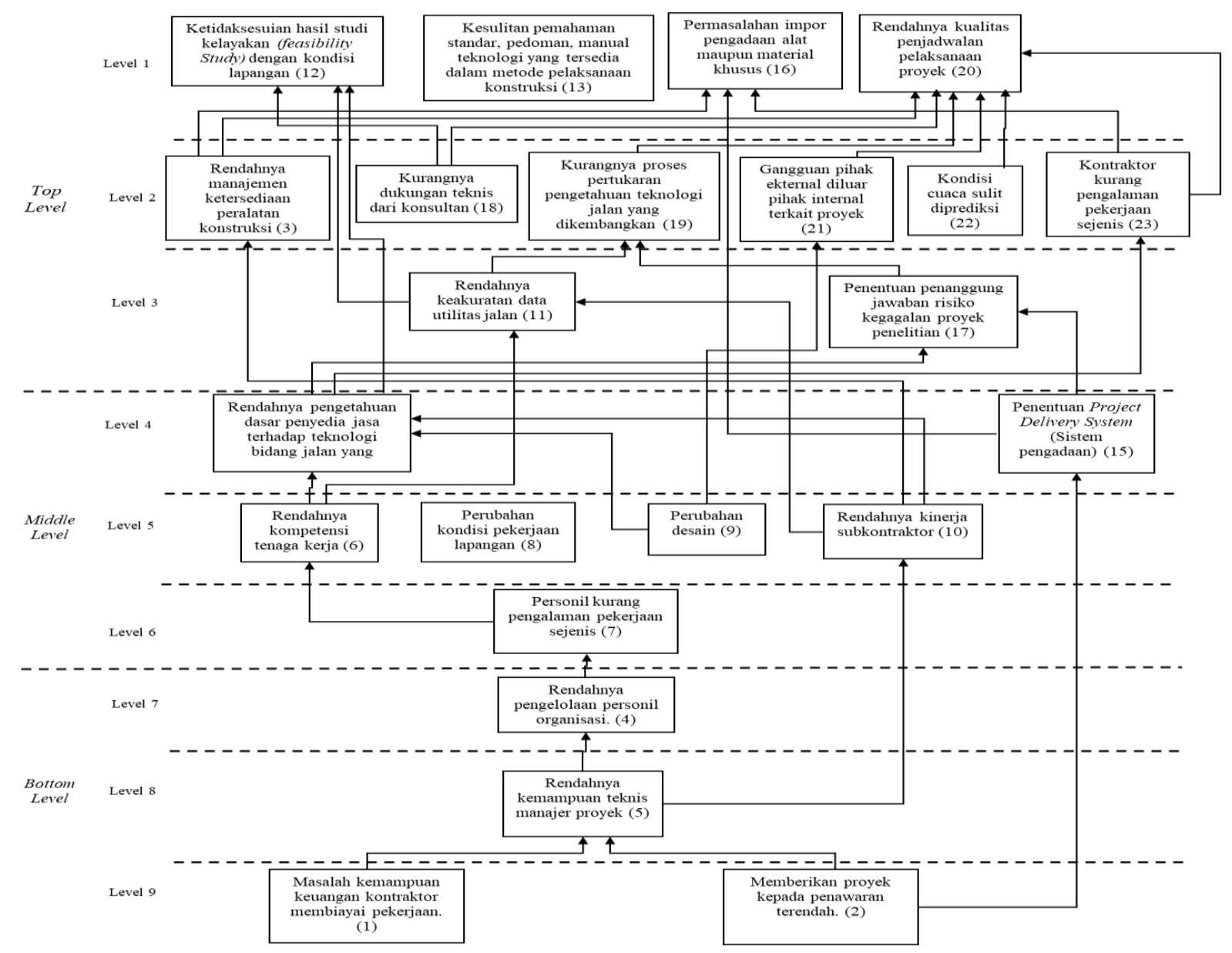

Gambar 3. Pemodelan Keterkaitan Faktor Kendala Penerapan Teknologi Terbatas (Pilot Project)Bidang Jalan Melalui Penyedia Jasa

b. Hasil identifikasi hubungan kontekstual terhadap 23 faktor kendala diperoleh 9 level hierarki model ISM yang dikelompokkan kedalam 3 kluster diantaranya, top level dengan 12 faktor kendala, middle level dengan 7 faktor kendala, bottom level dengan 4 faktor kendala.

c. Hasil analisis MICMAC diperoleh 3 klasifikasi faktor diantaranya, pada independent factor terdapat 4 faktor kendala faktor kendala, diantaranya 1, 2, 4, 5, pada dependence factor terdapat 6 faktor kendala, diantaranya $12,13,16,17,19,20$, sedangkan pada autonomous factor terdapat 13 faktor kendala, faktor kendala diantaranya $3,6,7,8,9,10,11,14,15,18$, $21,22,23$.

d. Hasil analisis pemodelan ISM didapatkan faktor rendahnya kualitas penjadwalan pelaksanaan proyek (20) merupakan faktor kendala paling dipengaruhi sedangkan faktor masalah kemampuan keuangan kontraktor membiayai pekerjaan (1) dan faktor memberikan proyek kepada penawaran terendah (2) menjadi faktor kunci paling mempengaruhi terhadap faktor kendala lain.

e. Usulan solusi yang dapat disampaikan berdasarkan hasil analisis ISM dan analisis MICMAC. Dalam upaya menghilangkan pemicu dan memutuskan rantai hubungan kontekstual yang saling mempengaruhi maka faktor masalah kemampuan keuangan kontraktor membiayai pekerjaan (1) dan faktor memberikan proyek kepada penawaran terendah (2) (faktor kunci) menjadi prioritas untuk diselesaikan . 


\section{DAFTAR PUSTAKA}

[1] Indonesia, Peraturan Menteri Pekerjaan Umum Nomor 07/PRT/M/2012 tentang Penyelenggaraan Penelitian dan Pengembangan Bidang Jalan, Jakarta : Kementerian Pekerjaan Umum dan Perumahan Rakyat, 2012.

[2] Indonesia, Rencana Strategis (renstra) Badan Penelitian dan Pengembangan Tahun 20152019, Jakarta: Kementerian Pekerjaan Umum dan Perumahan Rakyat, 2015

[3] Hendrawan, H., Faktor Yang Mempengaruhi Keberhasilan Penerapan Teknologi Terbatas Bidang Jalan Dengan Design And Build. Media Komunikasi Teknik Sipil, Vol 24, No. 1, 2018: 45-53.

[4] Indonesia, Undang-Undang Nomor 38 Tahun 2004 tentang Jalan. Lembaran Negara Republik Indonesia, Jakarta : Sekretariat Negara, 2004: 132.

[5] Indonesia, Peraturan Menteri Pekerjaan Umum dan Perumahan Rakyat Nomor
05/PRT/M/2015 tentang Pedoman Umum Implementasi Konstruksi Berkelanjutan Pada Penyelenggaraan Infrastruktur Bidang Pekerjaan Umum dan Permukiman, Jakarta : Kementerian Pekerjaan Umum dan Perumahan Rakyat, 2015.

[6] Peraturan Presiden Nomor 16 tahun 2018 tentang pengadaan barang dan jasa Pemerintah, Jakarta, 2018.

[7] Hasson, F., \& Keeney, S., \& McKenna H., Research Guidelines For The Delphi Survey Technique. Journal of Advanced Nursing, Vol. 32, No. 4, 2000: 1008-1015

[8] Munawaroh, S., \& Hanifa, F. M., \& Wiyono, N., \& Hastami, Y., \& Kartikasari, M. N. D., \& Hermasari, B. K., Delphi Technique: Consensus Of Anatomy Circulatory System Core Syllabus For Medical Student. Jurnal Pendidikan Kedokteran Indonesia, Vol. 7, No. 2, 2018: 107-117 